\title{
Job Satisfaction on Employee Performance; Counterproductive Work Behavior and Organizational Citizenship Behavior as Mediations
}

\author{
Roby Sambung \\ Faculty of Economy and Business, University of Palangka Raya, Center of Kalimantan, Indonesia
}

\section{Email address:}

roby.sambung@feb.upr.ac.id

\section{To cite this article:}

Roby Sambung. Job Satisfaction on Employee Performance; Counterproductive Work Behavior and Organizational Citizenship Behavior as Mediations. International Journal of Economic Behavior and Organization. Vol. 7, No. 3, 2019, pp. 50-56.

doi: $10.11648 /$ j.ijebo.20190703.12

Received: August 25, 2019; Accepted: November 6, 2019; Published: November 21, 2019

\begin{abstract}
Employee performance is one of the most researched topics in the field of human resources, many factors affect an employee's performance. As a negative behavior Counterproductive Work Behavior (CWB) which is often shown by employees when working, especially in government organizations. This behavior greatly affects the performance of employees in an organization. In addition to the negative behavior, positive behavior that has the opposite effect in improving employee performance is Organizational Citizenship Behavior (OCB). These two things are of concern to researchers to be studied in this study within a theoretical framework of research. Both CWB and OCB are largely determined by the job satisfaction felt by employees. This study aims to examine the effect of job satisfaction on OCB and CWB and the impact on employee performance, and wants to prove that $\mathrm{OCB}$ and $\mathrm{CWB}$ are able to mediate the relationship between job satisfaction and employee performance. Respondents from this study were 126 civil servants from 30 government offices with a simple random sample technique. The collected data were analyzed using the Structural Equation Modeling (SEM) approach with the Partial Least Square (PLS) approach. The results showed that OCB and CWB were proven to be mediators. For direct influence is explained in this text.
\end{abstract}

Keywords: Job Satisfaction, OCB, Counterproductive Work Behavior, Employee Performance

\section{Introduction}

Employee Performance is one of the most investigated topics in the science of human resources. Job satisfaction is the most influential factor on employee performance [27], [35]. The satisfaction in the workplace is one of the factors affecting the rise of negative behaviors in the workplace, such as the low presence rate in the office, finishing the work carelessly, even showing inattentive behavior. These harmful behaviors even some immensely disturbing behaviors are categorized into the behavioral category known as Counterproductive Work Behavior [13]. These deviant behaviors become one of the commonly faced behaviors in the public sector organization in Indonesia in general. That more than $50 \%$ of the civil servants have taken a break and go home as they desire, using office facilities such as the internet to watch YouTube, online shopping, or any other things unrelated to their work is more than $63.2 \%$. Using more working hours to interact or use social media (Facebook, Instagram, Twitter, WhatsApp, Line, YouTube, online game, and online shopping, etc.) as much as $41.2 \%$ have done it and they tend to do it often [15]. Same goes with talking behind their coworkers or colleagues' back about bad things, almost all of them have done it from the intensity of rare until often. Form that description, it shows that civil servants have the tendency to do the activities, even at oftentimes, known as Counterproductive Work Behavior.

A massive Counterproductive Work Behavior can immensely affect not only the organization but also the other stakeholders [9].

Counterproductive Work Behavior can be seen as a form of protest where the members of an organization express their dissatisfaction with or trying to solve the injustice in the organization [11]. There is a significant difference between 
Counterproductive Work Behavior occurs in the governmental organizations and the organization in the private sector, where CWB is most likely to happen in the public sector organization or governmental organization [24]. Job Satisfaction is one of the concerned factors which can reduce CWB in the governmental organization. Employees Job Satisfaction can lower the factor Counterproductive Work Behavior [19]. Therefore, in this research, Job Satisfaction is a factor that will be investigated regarding its effect on Employee Performance and CWB as the mediator.

Job Satisfaction also has its role in improving the Organizational Citizenship Behavior (OCB), the findings of [18], revealed that extrinsic and intrinsic Job Satisfaction is very important in predicting the behavior of citizenship behavior. Besides CWB is a negative characteristic, there is a positive behavior, in which on its development, researchers take their interests on the performance element which surpasses the actual work performance or known as organizational citizenship behavior, or OCB [17, 26, 27]. The positive behavior is very contradictory to CWB. Nowadays, many organizations strive to develop the behavior and attitude containing OCB.

In several studies, it is obvious that the job satisfaction of an employee significantly affects an individual behavior in the workplace, both positive behavior or OCB and negative behavior or CWB. The more satisfied the employees, the higher the tendency to show a positive behavior or OCB. On the other hand, the less satisfied an employee in the workplace, the higher their tendency to show negative behavior or CWB. Both directly and indirectly, it will also significantly affect the achievement of employee performance.

\subsection{Job Satisfaction (JS)}

Employee Satisfaction is the measurement of employee satisfaction on their work, whether they like their job or individual aspect or work aspect, such as the characteristics of the work or supervisor [29]. In several studies, the researchers also noted that the measurement of job satisfaction is varied according to how far they measure their feelings on their job or experienced as affective job satisfaction [33]. One of the most used definitions in the organizational research is developed [14], which defines Job Satisfaction as "the pleasant or positive emotional conditions generated from the work assessment or individual's work experience". A comprehensive definition of job satisfaction includes a reaction or cognitive, affective, and evaluative behavior and it is stated that job satisfaction is "the pleasant or positive emotional condition originated from work assessment or individual's work experience. According to the statement, job satisfaction is an individual behavior on the work experienced in their workplace. The behavior originates from their perspective on their job. Similarly, job satisfaction has also been conceptualized as arising when the job fulfils employee's needs [7].

Job Satisfaction is closely related to an individual's effort in working. The employees who are dissatisfied with their work will tend to work not optimally, not striving to do the best, and rarely make time and work extra to do their job. Realizing this, then one of the important targets in human resource management is the establishment of organization members' job satisfaction which will improve the work performance. Job Satisfaction in this research is the emotional reaction and behavioral expression on the expected phenomenon from the results of the individual assessment on the improvement opportunities, work achievement, the way of the chairmen corporate, colleague relations, opportunity to help people, the amount of compensation received. The indicators employed in this research refer to the research conducted [16]. and developed in this research.

This research is one of the research models in the field of employee performance development that is different from other researchers because this research examines and explains in one research model about the mediating role of positive behavioral factors is OCB and negative behaviors is CWB that have never been studied before. This study tries to explain the negative behaviors that often occur in government organizations, especially in Indonesia, so that negative and positive factors will be able to have implications on the performance of government employees.

\subsection{Organizational Citizenship Behavior (OCB)}

In recent years there has been increasing evidence that satisfaction has a different contribution, although it is not closely related to individual productivity, it is referred to as organizational citizenship behavior (OCB). In addition, research in the last two decades has enriched the theoretical and empirical knowledge base of OCB, examining its relationship with culture, attitudes, personality, mood states, stress, and [22]. Employees are compensated for executing the tasks entailed in their job description. However, employees may do more than is required. They may help each other out when necessary, take the time to advice, coach, or mentor each other, or volunteer for extra work assignments [8]. These behaviors, which are not typically required contractually from employees, are illustrative of OCB [37]. There is no additional incentive given when extrarole is performed. Compared to the in-role behavior, it is connected with extrinsic or monetary awards, the on the extra-role is more related to the intrinsic awards [36]. This behavior emerges due to the feeling and satisfaction of the organizational members when performing "something more" for the organization. These behaviors describe "employee point plus" and one of the forms of pro-social behavior, which is a positive, constructive, and helpful social behaviors [2]. OCB as an individual behavior of being free and unrelated directly or explicitly with the reward system and can improve the effective function of an organization [21].

OCB found as an explanation alternative on "satisfaction based on performance" hypothesis [20]. From the definitions stated in several studies on OCB, it can be concluded that 1) the voluntary behavior is not forced behavior on the aspects that priorities the organizational interests, 2) individual behavior as the realization of the satisfaction based on 
performance, not being ordered formally, and 3) not related directly and openly with the formal reward system [27]. OCB is seen broadly as the factor which gives a contribution to the results of organizational performance thoroughly. This research refers to five aspects developed by Organ [20] and modified by the researcher, which the helpful behavior of the employee, showing voluntary participation, alleviating other people's problems, the prohibition of creating bad issues and assisting coworkers.

\subsection{Counterproductive Work Behavior (CWB)}

The behavior is defined as "dysfunctional" because it almost always violates the major norms in the organization and performs behaviors irrelevant to their visions, violates procedures, decreases productivity and profitability [12], [15]. Counterproductive Work Behavior can also affect human resources in the organization, where it is mentioned that Counterproductive Work Behavior can cause dissatisfaction feeling and stress, and then leads to the intention to leave the organization, have a low confidence, and lower the trustworthy of workplace, as well as experiencing heartache both physically and psychologically [4]. Counterproductive Work Behavior (CWB) is the negative behavior of the employee contradictory to the organizational interests [25]. This research developed eight indicators developed by [30] in the dimension of counterproductive work behavior.

\subsection{Employee Performance (EP)}

The definition of is value shown by employees in performing their job which is valuable and meaningful to the organization. The contribution shown by the employee both directly and indirectly aimed at achieving the vision of the organization [23]. Define job performance as the standard for advancements, redundancy, rewards, punishments, reviews and salary changes [6]. It also satisfies the needs for employees to realize themselves employee performance symbolizes the broad belief of the personnel about their behavior and contributions towards the achievement of the organization [2]. The five items used in this research were developed from several researchers, such as giving the best performance service, acting according to the norms and ethics, prioritizing the organization's interests, being on time in doing the task, arriving on time at the office according to the break time and leaving time from the office, cooperate well in completing the job and giving positive encouragement to the coworkers.

\subsection{The Effect Between Job Satisfaction and OCB}

The research which has examines the positive effect on Job Satisfaction and OCB is the research conducted [32, 26-28]. The research results showed that Job Satisfaction positively affects OCB. Therefore, there is a hypothesis between Job Satisfaction and OCB:

Hypothesis 1. Job Satisfaction positively affects OCB

\subsection{The Effect Between Job Satisfaction and CWB}

There are numerous studies explain that Job Satisfaction affects positively on CWB among them is [19, 3]. The results of the study explained that the more satisfied someone is towards the work environment, relationships with superiors, relations with colleagues, the level of justice of the boss, and then they can reduce the negative behavior that will arise in the organization. Therefore, a hypothesis can be made from the research results.

Hypothesis 2. Job Satisfaction negatively affects CWB

\subsection{Correlation Between Job Satisfaction and Employee Performance}

The theoretical correlation between Job Satisfaction and work performance or employee performance become widely studied topics in these several decades, so the explanation on the more satisfied an employee the more they show their work performance. Job Satisfaction affects the work performance or Employee Performance [27]. Thus, a hypothesis can be made stating that:

Hypothesis 3. Job Satisfaction positively affects Employee Performance

\subsection{Correlation Between OCB and Employee Performance}

OCB affects work performance or employee performance $[26,27,5]$. The results concluded that the better the positive behaviors of an employee shown by the extra-role behavior, the more likely the employee to have superior performance. Thus, from this statement then a correlation between concepts is stated in the following hypotheses:

Hypothesis 4. OCB positively affects Employee Performance

Hypothesis 5. OCB as a positive mediator of Job Satisfaction and Employee Performance

\subsection{Correlation Between CWB and Employee Performance}

Researchers on counterproductive work behavior stated that $\mathrm{CWB}$ is a negative behavior often experienced in the organization, particularly governmental organizations. Due to the characteristic of this behavior is negative; it can lower employee performance or work performance. CWB negatively affects the performance $[12,4,25,30]$. Therefore, the researcher made a statement in the following hypothesis.

Hypothesis 6. CWB negatively affects to Employee Performance

Hypothesis 7. CWB as a mediator for Job Satisfaction and Employee Performance

\subsection{Research Framework}

Thus, in this research, a research model was developed to test the negative and positive behaviors in a research model as illustrated in the research model in Figure 1 below. 


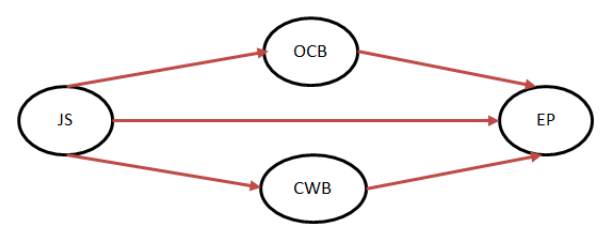

Figure 1. The Conceptual Framework of the Research.

Description:

JS: Job Satisfaction;

OCB: Organizational Citizenship Behavior

CWB: Counterproductive Work Behavior

EP: Employee Performance

\section{Methods}

The research method was quantitative research because the analysis emphasized the numeric data. The population was civil servants who work in Palangka Raya City Government. The samples taken were 136 people from five offices who conduct direct public services. The data collection employed questionnaires with a Likert scale starts from strongly agree to strongly disagree. The data analysis utilized the SmartPLS version 3 approach. PLS is an SEM model approach without assumption on the data distribution (Vinzi et al., 2010). Thus, PLS-SEM became a good alternative to predict a model and test a weak model.

\section{Research Results}

\subsection{Characteristics of Respondents}

The respondents in this research were civil servants in 5 offices in Palangka Raya city Central Kalimantan Province. The samples who were the respondents in this research were all civil servants taken or chosen randomly around 136 people but only 126 questionnaires were filled, therefore the latest data used were 126 respondents. The respondents' characteristics are illustrated in Table 1 below.
Table 1. Characteristics of Respondents.

\begin{tabular}{lll}
\hline Characteristics & Frequency & \% \\
\hline Based on Gender & 55 & \\
Males & 71 & 44 \\
Females & 126 & 56 \\
Total & & 100 \\
Based on age & 13 & \\
$<30$ years old & 38 & 10 \\
31 - 40 years old & 75 & 30 \\
$>41$ years old & 126 & 60 \\
Total & 17 & 100 \\
Based on the latest education & \\
SMA & 19 & 13 \\
D3 & 68 & 15 \\
S1 & 22 & 54 \\
S2 & - & 17 \\
S3 & 126 & - \\
Total & 100 \\
Based on the working experience & \\
$<5$ years old & 10 & 8 \\
6 - 10 years old & 36 & 29 \\
$>11$ years old & 80 & 63 \\
Total & 126 & 100 \\
Based on the marital status & & \\
Not married & 6 & 5 \\
Married & 117 & 93 \\
Widow or Widower & 3 & 2 \\
Total & 126 & 100 \\
\hline
\end{tabular}

Table 1 above explains that the respondents in this research are dominated by female civil servants as much as $56 \%$ with $54 \%$ has a bachelor's degree and $63 \%$ have more than 11 years of service and the marital status is married.

\subsection{The Results of Analysis}

For the outer model consisting of the convergent validity and internal validity results, it is summarized in Table 2 below:

Table 2. The Results of Convergent Validity and Internal Reliability.

\begin{tabular}{|c|c|c|c|c|}
\hline Latent Variables & Indicators & Outer Loading & AVE & Composite Reliability \\
\hline \multirow{3}{*}{ Job Satisfaction (JS) } & The way of the boss cooperate (KK4) & 0.775 & \multirow{3}{*}{0.637} & \multirow{3}{*}{0.840} \\
\hline & Coworkers (KK5) & 0.840 & & \\
\hline & Opportunities to help (KK6) & 0.778 & & \\
\hline \multirow{4}{*}{ OCB } & Helping the absent coworker (OCB1) & 0.754 & \multirow{4}{*}{0.683} & \multirow{4}{*}{0.928} \\
\hline & Helping the coworker who has more workload (OCB2) & 0.868 & & \\
\hline & Making time to listen to coworkers (OCB3) & 0.827 & & \\
\hline & Helping and sharing knowledge with the new coworker (OCB4) & 0.841 & & \\
\hline \multirow{3}{*}{$\begin{array}{l}\text { Counterproductive Work } \\
\text { Behavior (CWB) }\end{array}$} & Giving negative comments to anyone (CWB1) & 0.850 & \multirow{3}{*}{0.679} & \multirow{3}{*}{0.894} \\
\hline & Underestimating the ability of coworker (CWB2) & 0.832 & & \\
\hline & Not performing the task effectively (CWB3) & 0.686 & & \\
\hline \multirow{5}{*}{ Employee Performance (EP) } & Giving the best work service (KP1) & 0.787 & \multirow{5}{*}{0.628} & \multirow{5}{*}{0.834} \\
\hline & Acting according to norms and ethics (KP2) & 0.764 & & \\
\hline & Prioritizing the organization's interests (KP3) & 0.812 & & \\
\hline & Being on time (KP4) & 0.826 & & \\
\hline & Cooperating well (KP5) & 0.870 & & \\
\hline
\end{tabular}

Table 2 above showed that all items on each variable obtain the outer loading value $>0.6$, this result fulfills the requirement of convergent validity; AVE value $>0.5$, this measurement fulfills the requirement of convergent validity 
from AVE value and CR value $>0.7$ meaning that all latent variables are reliable, thus, the questionnaires used as an instrument in this research has been reliable or consistent. Therefore, it can be concluded that all indicators have become each construct measurer. The structural model or inner model was evaluated by looking at the percentage of described variance with the R-square $\left(R^{2}\right)$ value to construct a dependent latent from the following Table 3 .

Table 3. $R$-square $\left(R^{2}\right)$ Values of Endogen Variables.

\begin{tabular}{lll}
\hline Endogen variables & R Square & Adjusted R Square \\
\hline Performance & 0.261 & 0.243 \\
OCB & 0.110 & 0.103 \\
CWB & 0.143 & 0.136 \\
\hline
\end{tabular}

The criteria of determining R-Square $\left(\mathrm{R}^{2}\right)$, which is low $\mathrm{R}^{2}$ $=0.02 ;$ medium $\mathrm{R} 2=0.13$; high $\mathrm{R} 2=0.26$ [38]. The calculation results from Table 3 above shows the R-Square value for each endogen variable. The effect of Job Satisfaction variable on OCB is 0.103 or equal to $10.3 \%$ which means that the effect of job satisfaction variable on OCB is categorized as medium The effect of Job Satisfaction variable on $\mathrm{CWB}$ is 0.143 or $14.3 \%$ meaning that it is medium and the effect of Job Satisfaction, OCB, and CWB on performance is 0.261 or $26.1 \%$ meaning that it is categorized as high.

The testing of the Goodness of Fit structural model on the inner model employed predictive-relevance $(\mathrm{Q} 2)$ value. Q Square predictive relevance was obtained from the $Q^{2}$ value of 0.413 , the value has not reached 1 . Then, it can be concluded that the model is in the medium category. Besides looking for $\mathrm{Q}$ - Square predictive relevance $(\mathrm{Q} 2)$, the Goodness of Fit (GoF) value calculation is needed. Different from CBSEM, for GoF value on PLS-SEM it has to be found manually. Small GoF value $=0.1$, medium $\mathrm{GoF}=0.25$ and GoF high $=0.38$. The research result on the Goodness of Fit (GoF) value was 0.757628 categorized as high [39].

Table 4. Hypothesis Testing Direct Effect.

\begin{tabular}{|c|c|c|c|c|c|c|}
\hline Influence between variables & Original Sample & Sample Mean & Deviation Standard & T Statistics & P Values & Description \\
\hline Job Satisfaction -> Performance & 0.132 & 0.136 & 0.083 & 1.588 & 0.112 & Insignificant \\
\hline Job Satisfaction $->$ OCB & 0.331 & 0.339 & 0.083 & 4.011 & 0.000 & Significant*) \\
\hline Job Satisfaction $->$ CWB & -0378 & -0.393 & 0.070 & 5.422 & 0.000 & Significant*) \\
\hline OCB $->$ Performance & 0.347 & 0.343 & 0.077 & 4.532 & 0.000 & Significant*) \\
\hline CWB $->$ Performance & -0.213 & -0.222 & 0.090 & 2.355 & 0.019 & Significant*) \\
\hline
\end{tabular}

*) significant at $\alpha 1 \%$ or 0.01

Table 5. Hypothesis Testing Indirect Effect.

\begin{tabular}{|c|c|c|c|c|c|c|}
\hline Influence between variables & Original Sample & Sample Mean & Deviation Standard & T Statistics & P Values & Description \\
\hline Job Satisfaction ->OCB--> Performance & 0,115 & 0,116 & 0,038 & 3,050 & 0,002 & Significant*) \\
\hline Job Satisfaction $->$ CWB--> Performance & 0,081 & 0,087 & 0,039 & 2,056 & 0,040 & Significant**) \\
\hline
\end{tabular}

*) significant at $\alpha 1 \%$ or 0.01

**) significant at $\alpha 5 \%$ or 0.05

\section{Discussion}

Based on the table 4 the research results showed that Hypothesis 1 stated that Job Satisfaction positively affects OCB is accepted, Hypothesis 2 which states that Job Satisfaction negatively affects CWB is accepted; Hypothesis 3 which states that Job Satisfaction positively affects performance is rejected. Hypothesis 4 states that OCB positively affects Employee Performance is accepted. Hypothesis 6 stated that CWB negatively affects the received employee performance is accepted.

Based on the table 5 the research results showed Hypothesis 5 OCB as a positive mediator of Job Satisfaction and Employee Performance is accepted. Hypothesis $7 \mathrm{CWB}$ as a negative mediator for Job Satisfaction and Employee Performance is accepted.

\section{Conclusion}

The result is shown job Satisfaction positively affects to $\mathrm{OCB}$, it explains that this research supports the previous studies such as [26, 27]. Job Satisfaction negatively affects to $\mathrm{CWB}$, the results of this hypothesis also support the research [19,3]. The effect of job satisfaction on employee performance directly has no effect, this testing result is contradictory to the research conducted [27]. The differences of the findings explain that in the condition of the governmental organization, Job Satisfaction does not become a benchmark for the employees directly to show their work performance. It can be seen from the condition in the field where the employees tend to show their performance by being present in the office actively by doing checking in and out of the attendance. However, it does not necessarily show the quantity and quality of their performance. In other words, being present in the office and proven with full list of attendance, it becomes one of their satisfaction, but not in completing their tasks and work, so that the negative behavior tends to be shown is the Counterproductive Work Behavior, after doing the checking in they can go out of the office with unclear intentions, then coming back nearly going home hour. OCB positively affects Employee Performance. The hypothesis testing results support the research results done 
obtained [26, 27, 5], explain that OCB is capable of improving the work performance or employee performance better. CWB negatively to employee performance. This explains that the higher the negative behavior of an employee or known as CWB, the lower their employee work performance. Negative behaviors or CWB intended in this research include being present only for the check log then going outside the office, going home earlier, coming late, using office facilities for personal interest, using more time to open social media, doing online shopping, backbiting, and gossiping on bad things.

The findings of this study also explain that the role of OCB as a mediator has a positive effect on job satisfaction and employee performance. CWB has a negative effect as a mediator variable on job satisfaction and employee performance.

The results of this research can be concluded that positive behavior known as OCB is a behavior that can improve employee performance well. However, employee satisfaction must be fulfilled. The intended satisfaction is an emotional reaction and behavioral expression on the expected phenomenon with the actual phenomenon from the results of the individual assessment on the opportunity to develop, work achievement, the way the boss cooperates, relationship with co-workers, opportunities to help people and the amount of the received compensation. Similarly, negative behavior or CWB is a behavior that needs to be reduced maximally by paying attention to employee job satisfaction such as increasing knowledge-sharing between co-workers, doing justice, increasing employee involvement in many opportunities and work. This is proven that CWB can mediate in a negative direction to achieve bad performance. Therefore, these two behaviors need to be paid attention to in the governmental organization. The improvement of OCB can be conducted along with the number of employee character-building development being conducted, doing some motivating activities and improving employee's commitment so that they have superior working performance. Then the chairmen in the governmental organization can be more sensitive to the employees who show deviant behavior. This can occur when there is a decrease in satisfaction in an organization; feeling not considered well, treated injustice and other forms of attitude and behaviors from the boss or co-workers so that it creates a working environment that makes the employee feel dissatisfied.

\section{Recommendations}

The weakness of this research is the difference in the research results which explains the correlation between Job Satisfaction and work performance or Employee Performance. This becomes an opportunity for the future researchers to be able to develop this research by adding several variables which can improve the employee performance directly.

\section{References}

[1] Ahmad, S., \& Shahzad, K. (2011). HRM and employee performance: A case of university teachers of Azad Jammu and Kashmir (AJK) in Pakistan. African journal of business management, 5 (13), 5249-5253.

[2] Aldag, R., \& Reschke, W. (1997). Employee value-added. Center for organizational effectiveness Inc.

[3] Biduani, 2018. Pengaruh kepuasan kerja terhadap perilaku kerja kontraproduktif melalui organizational Citizenship behavior (OCB), Studi pada Pemerintah Kota Palangka Raya. Tesis Magister Sains Manajemen, Program Pascasarjana Universitas Palangka Raya.

[4] Chernyak-Hai, L., \& Tziner, A. (2014). Relationships between counterproductive work behavior, perceived justice and climate, occupational status, and leader-member exchange. Revista de Psicología del Trabajo y de las Organizaciones, 30 (1).

[5] Chiang, C. F., \& Hsieh, T. S. (2012). The impacts of perceived organizational support and psychological empowerment on job performance: The mediating effects of organizational citizenship behavior. International journal of hospitality management, 31 (1), 180-190.

[6] Chin-Wen Liao. (2012). Work values, work attitude and job performance of green energy industry employees in Taiwan. African Journal Of Business Management. https://doi.org/10.5897/ajbm11.1449

[7] Erdogan, B., Bauer, T. N., Truxillo, D. M., \& Mansfield, L. R. (2012). Whistle While You Work: A Review of the Life Satisfaction Literature. Journal of Management. https://doi.org/10.1177/0149206311429379

[8] Fox, S., Spector, P. E., Bruursema, K., Kessler, S., \& Goh, A. (2007). Necessity is the mother of behavior: Organizational constraints, CWB and OCB. In meeting of the Academy of Management, Philadelphia, PA.

[9] Hafidz, S. W. M. (2012). Individual differences as antecedents of counterproductive work behavior. Asian Social Science, 8 (13), 220 .

[10] Judge, T. A., Thoresen, C. J., Bono, J. E., \& Patton, G. K. (2001). The job satisfaction-job performance relationship: A qualitative and quantitative review. Psychological Bulletin, $127(3), 376$.

[11] Kelloway, E. Kevin., Francis, Lori., Process, Matthew r., dan Cameron, James E. 2010. Counterproductive work behavior as protest, Human Resource Management Review 20 (2010) 18 25

[12] Klotz, A. C., \& Buckley, M. R. (2013). A historical perspective of counterproductive work behavior targeting the organization. Journal of Management History, 19 (1), 114132 .

[13] Kreitner, R., \& Kinicki, A. (2014). Perilaku Organisasi (Organizational Behavior) (Edisi-9). Jakarta: Salemba Empat.

[14] Locke, E. A. (1976). The nature and causes of job satisfaction. Handbook of industrial and organizational psychology. 
[15] Mahjuri. 2016. Pengaruh kepribadian terhadap perilaku kerja Kontraproduktif melalui kecerdasan Emosional dan kecerdasan spiritual (studi pada pemerintah kota palangka raya), Tesis Program Magister Sains Manajemen Pascasarjana Unpar.

[16] Martins, H., \& Proença, T. (2012). Minnesota Satisfaction Questionnaire-Psychometric properties and validation in a population of Portuguese hospital workers. FEP JournalEconomics \& Management: Working Paper, 471 (1).

[17] Miles, D. E., Borman, W. E., Spector, P. E., \& Fox, S. (2002). Building an integrative model of extra-role work behaviors: A comparison of counterproductive work behavior with organizational citizenship behavior. International Journal of Selection and Assessment, 10 (1 - 2), 51-57.

[18] Mohammad, J., Quoquab Habib, F., \& Alias, M. A. (2011). Job Satisfaction and Organisational Citizenship Behaviour: an Empirical Study at Higher Learning Institutions. Asian Academy of Management Journal, 16 (2).

[19] Mount, M., Ilies, R., \& Johnson, E. (2006). Relationship of personality traits and counterproductive work behaviors: The mediating effects of job satisfaction. Personnel Psychology, 59 (3), 591-622.

[20] Organ, D. W. (1988). Organizational citizenship behavior: The good soldier syndrome. Lexington Books/DC Heath and Com.

[21] Organ, D. W. (1990). The motivational basis of organizational citizenship behavior. Research in organizational behavior, 12 (1), 43-72.

[22] Organ, D. W. (2018). Organizational citizenship behavior: Recent trends and developments. Annual Review of Organizational Psychology and Organizational Behavior, 80, 295-306.

[23] Rich, B. L., Lepine, J. A., \& Crawford, E. R. (2010). Job engagement: Antecedents and effects on job performance. Academy of management journal, 53 (3), 617-635.

[24] Rusdi, Zainnur M. 2014. Analisis perilaku kerja kontra produktif pada pegawai negeri sipil di bandar lampung. Jurnal Bisnis dan Manajemen, ISSN 1411 - 9366 Volume 10 No. 2, Januari 2014

[25] Sackett, P. R., Berry, C. M., Wiemann, S. A., \& Laczo, R. M. (2006). Citizenship and counterproductive behavior: Clarifying relations between the two domains. Human Performance, 19 (4), 441-464.

[26] Sambung, Roby. (2011). Pengaruh Kepuasan Kerja Terhadap OCB-I Dan OCB-O Dengan Dukungan Organisasi Sebagai Variabel Moderating (Studi pada Universitas Palangka Raya). Jurnal Analisis Manajemen, 5 (2), 77-90.

[27] Sambung, R., Thoyib, A., \& Troenam, E. A. Surachman. (2012). Pengaruh Kepuasan Kerja, Komitmen Organisasional, Kepribadian dan Profesionalisme Dosen terhadap Organizational Citizenship Behavior serta Dampaknya terhadap Kinerja Dosen (Studi pada Univ Palangka Raya). Jurnal Aplikasi Manajemen, 10 (1), 12-20.

[28] Sendjaya, S., Pekerti, A. A., Cooper, B. K., \& Zhu, C. J. (2019). Fostering organisational citizenship behaviour in Asia: The mediating roles of trust and job satisfaction. In Leading for High Performance in Asia: Contemporary Research and Evidence-Based Practices. https://doi.org/10.1007/978-98113-6074-9_1

[29] Spector, P. E. (1997). Job satisfaction: Application, assessment, causes and consequences. Thousand Oaks, CA: SAGE.

[30] Spector, P. E., Fox, S., Penney, L. M., Bruursema, K., Goh, A., \& Kessler, S. (2006). The dimensionality of counterproductivity: Are all counterproductive behaviors created equal?. Journal of vocational behavior, 68 (3), 446460 .

[31] Smith, C. A., Organ, D. W., \& Near, J. P. (1983). Organizational citizenship behavior: Its nature and antecedents. Journal of applied psychology, 68 (4), 653.

[32] Tharikh, S. M., Ying, C. Y., Mohamed Saad, Z., \& Sukumaran, K. a/p. (2016). Managing Job Attitudes: The Roles of Job Satisfaction and Organizational Commitment on Organizational Citizenship Behaviors. Procedia Economics and Finance. https://doi.org/10.1016/s2212-5671(16)00074-5

[33] Thompson, E. R., \& Phua, F. T. (2012). A brief index of affective job satisfaction. Group \& Organization Management, 37 (3), 275-307.

[34] Vinzi, V. E., Trinchera, L., \& Amato, S. (2010). PLS path modeling: from foundations to recent developments and open issues for model assessment and improvement. In Handbook of partial least squares (pp. 47-82). Springer, Berlin, Heidelberg.

[35] Yuen, K. F., Loh, H. S., Zhou, Q., \& Wong, Y. D. (2018). Determinants of job satisfaction and performance of seafarers. Transportation Research Part A: Policy and Practice. https://doi.org/10.1016/j.tra.2018.02.006

[36] Wright, P. M., George, J. M., Farnsworth, S. R., \& McMahan, G. C. (1993). Productivity and extra-role behavior: The effects of goals and incentives on spontaneous helping. Journal of Applied Psychology, 78 (3), 374.

[37] Wörtler, B., Van Yperen, N. W., \& Barelds, D. P. H. (2019). Do individual differences in need strength moderate the relations between basic psychological need satisfaction and organizational citizenship behavior? Motivation and Emotion. https://doi.org/10.1007/s11031-019-09775-9

[38] Cohen, J. (1992). A power primer. Psychological bulletin, 112 (1), 155.

[39] Tenenhaus, M. (2004). A PLS approach to multiple table analysis. In Classification, Clustering, and Data Mining Applications (pp. 607-620). Springer, Berlin, Heidelberg. 